\title{
A Quaternary fault database for central Asia
}

\author{
Solmaz Mohadjer ${ }^{1}$, Todd Alan Ehlers ${ }^{1}$, Rebecca Bendick ${ }^{2}$, Konstanze Stübner ${ }^{1}$, and Timo Strube ${ }^{1}$ \\ ${ }^{1}$ Department of Geosciences, University of Tübingen, Tübingen, Germany \\ ${ }^{2}$ Department of Geosciences, University of Montana, Missoula, Montana, USA
}

Correspondence to: Solmaz Mohadjer (solmaz.mohadjer@gmail.com)

Received: 27 July 2015 - Published in Nat. Hazards Earth Syst. Sci. Discuss.: 23 September 2015

Revised: 14 January 2016 - Accepted: 26 January 2016 - Published: 24 February 2016

\begin{abstract}
Earthquakes represent the highest risk in terms of potential loss of lives and economic damage for central Asian countries. Knowledge of fault location and behavior is essential in calculating and mapping seismic hazard. Previous efforts in compiling fault information for central Asia have generated a large amount of data that are published in limited-access journals with no digital maps publicly available, or are limited in their description of important fault parameters such as slip rates. This study builds on previous work by improving access to fault information through a web-based interactive map and an online database with search capabilities that allow users to organize data by different fields. The data presented in this compilation include fault location, its geographic, seismic, and structural characteristics, short descriptions, narrative comments, and references to peer-reviewed publications. The interactive map displays 1196 fault traces and 34000 earthquake locations on a shaded-relief map. The online database contains attributes for 123 faults mentioned in the literature, with Quaternary and geodetic slip rates reported for 38 and 26 faults respectively, and earthquake history reported for 39 faults. All data are accessible for viewing and download via http: //www.geo.uni-tuebingen.de/faults/. This work has implications for seismic hazard studies in central Asia as it summarizes important fault parameters, and can reduce earthquake risk by enhancing public access to information. It also allows scientists and hazard assessment teams to identify structures and regions where data gaps exist and future investigations are needed.
\end{abstract}

\section{Introduction}

The ongoing collision of the Indian subcontinent with Asia results in active deformation and seismicity in the Indo-Asian collision zone (Fig. 1). Continental collision initiated in the early Cenozoic (ca. $55 \mathrm{Ma}$ ) and is marked by large spatial and temporal variations in deformation across the Himalaya and surrounding areas (e.g., Hodges, 2000; Avouac, 2007; Thiede and Ehlers, 2013). India-Eurasia collision has created a complex zone of deformation that is characterized by an intricate network of faults, some of which have historically caused devastating earthquakes and continue to pose threats to the population at risk. Seven of the 28 deadliest earthquakes reported for 1990-2014 (USGS, 2014) are located in this zone with magnitudes ranging from 6.1 to 7.9 (Fig. 1). According to the United States Geological Survey, these events caused at least 195796 fatalities in total, corresponding to $23 \%$ of total death toll reported for all deadly earthquakes in the world for the above period. Earthquakes in this region do not have to be particularly large to cause heavy damage. Only one of the 28 largest earthquakes reported for the above period is located within the India-Eurasia collision zone (i.e., the 2008 M7.9 Sichuan earthquake). Smaller events of magnitudes 6.1 and 6.6 that occurred in the Hindu Kush region in 2002 and 1998 respectively, caused over 5000 fatalities, and left about 10000 injured and tens of thousands homeless. To understand earthquakes and to address earthquake hazards, it is crucial to locate and characterize Quaternary faults accurately. In particular, fault location, earthquake history and cycle, as well as slip rate, are important input parameters that are used in calculations of earthquake hazards and probabilities. This information can serve as the basis for understanding faulting and earthquake behavior in the region (Trifonov and Kozhurin, 2010; Field et al., 2013; Wills et al., 


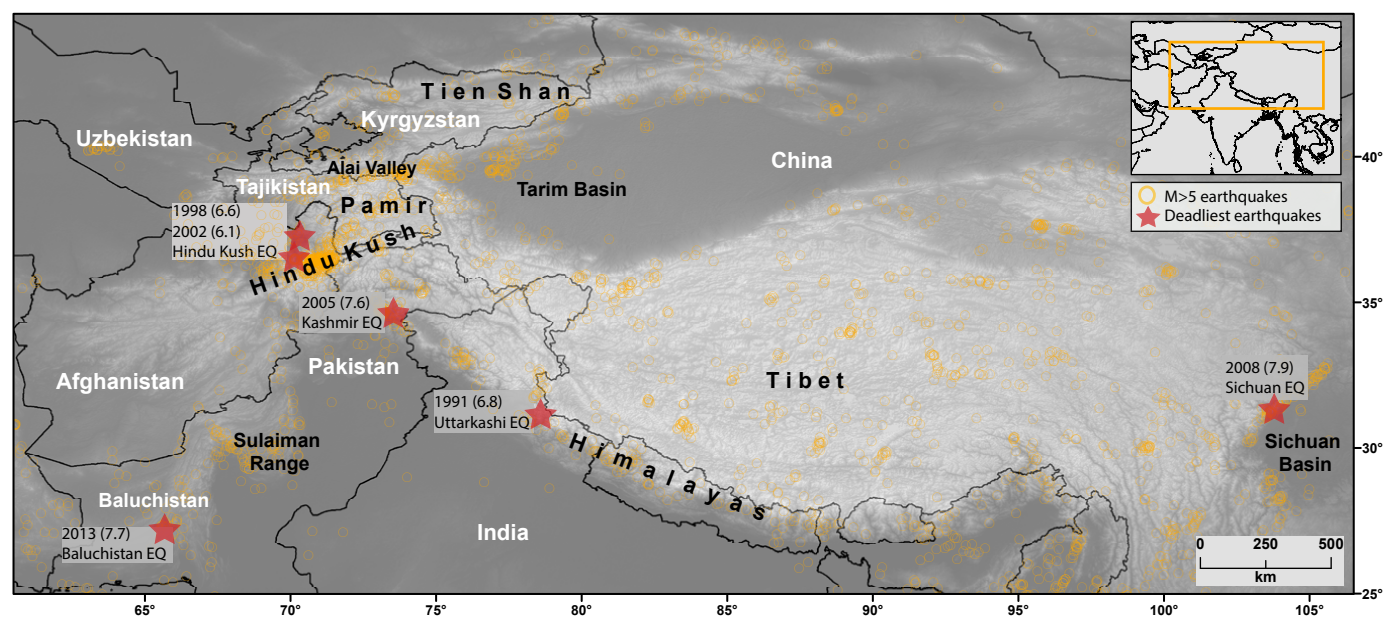

Figure 1. Map of the study area showing $M \geq 5$ earthquakes (orange circles) for the 1900-2014 period from ANSS Comcat (2014). Red stars mark the location of the deadliest earthquakes for the 1900-2014 period that are discussed in the text. The only exception is the 2001 M7.7 Bhuj earthquake which is located outside the study area, but it is still considered to be within the India-Eurasia collision zone.

2008; Plesch et al., 2007; Ruleman et al., 2007; Tapponnier et al., 2001).

Previous studies in central Asia have produced a large amount of data that enhance our understanding of regionaland continental-scale tectonics as well as seismic hazards in the region. Geodetic measurements using the Global Positioning System (e.g., Bendick et al., 2015; Ischuk et al., 2013; Mohadjer et al., 2010; Zubovich et al., 2010; Bendick et al., 2007; Reigber et al., 2001; Abdrakhmatov et al., 1996) and regional seismic investigations and catalogs (e.g., Feld et al., 2015; Schneider et al., 2013; Sippl et al., 2013; Mechie et al., 2012; Haberland et al., 2011; Mellors et al., 1995) continue to provide a more detailed pattern and rates of deformation associated with individual faults and other major structures. High-resolution imagery allows for more accurate mapping of previously recognized faults and their geomorphic expressions (e.g., Chevalier et al., 2012; Robinson, 2009; Taylor and Yin, 2009; Strecker et al., 2003), and a significant number of previously unknown, but potentially active structures have been detected and interpreted based on satellite images and digital topographic data (e.g., Ruleman et al., 2007). Despite being limited in their coverage, recent paleoseismologic studies (e.g., Schiffman et al., 2013; Korjenkov et al., 2012; Ran et al., 2010; He et al., 2007; Kumar et al., 2006; Washburn et al., 2003) provide improved constraints on the magnitude and recurrence time of past earthquakes for some faults. The paleoseismic history of many faults, however, remains poorly understood. Previous investigations have often been limited to the Himalayan main frontal thrusts (Kumar et al, 2001, 2006; Lavé et al., 2005) and other major structures such as the Kunlun and Altyn Tagh faults (He et al., 2007; Washburn et al., 2001, 2003, respectively), or were only conducted in the aftermath of large events such as the 2005 Kashmir and the 2008 Sichuan earthquakes (Kaneda et al., 2008 and Ran et al., 2010, respectively). A more complete paleoseismic record can enhance our understanding of fault behavior and earthquake hazard in the region. All data from previous work provide baseline observations for understanding patterns and rates of Quaternary faulting in central Asia.

Despite considerable advancements provided by previous work, there are several shortcomings that impede information sharing and adequate assessment of fault activity and hazards in the region. Previous investigations have generated data that are documented in a wide range of formats (e.g., digital, texts, maps, and images) that are often published in non-open access journals. This can make access, usage, and dissemination of fault data a time-consuming and resource-intensive task, particularly for non-academic users and the general public. Despite initiatives that aim to provide a centralized platform for storage, maintenance, and the display of fault data specific to other regions of the world such as the online Quaternary Fault and Fold Database of the United States Geological Survey (http://earthquake. usgs.gov/hazards/qfaults/), few attempts have been made for central Asian faults (e.g., Ioffe and Kozhurin, 1996; Ioffe et al., 1993; Trifonov, 2000). The HimaTibetMap of Taylor and Yin (2009) is currently the only publicly available digital database of active structures located in central Asia. Users can download and view fault location data on a semiinteractive map. The fault data, however, are unsearchable and limited to only a few parameters. The Global Earthquake Model Global Active Faults Database (http://www. globalquakemodel.org/) is currently being tested with no fault data from central Asia. Therefore, there is a clear need for an open-access database with fault information that focuses on central Asia. 

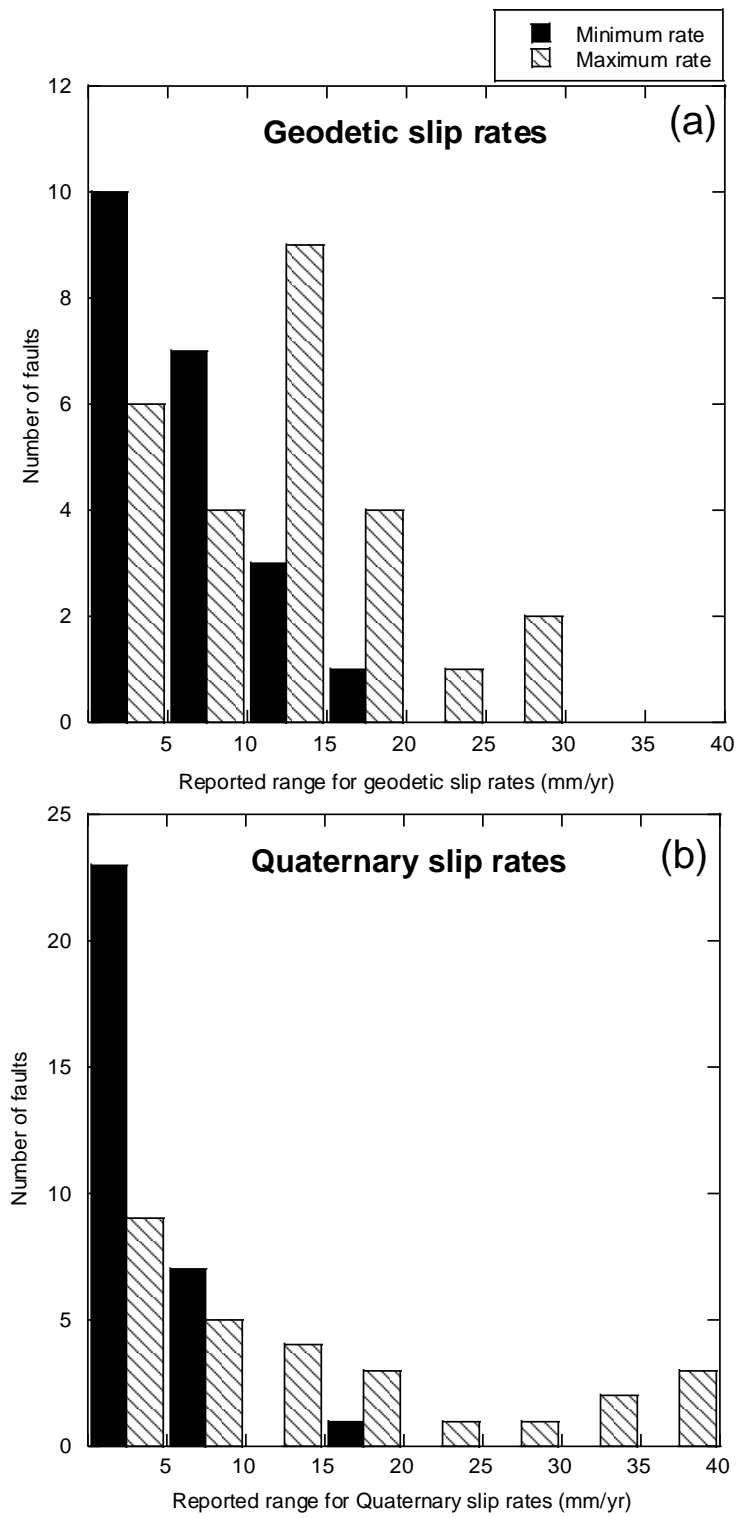

Figure 2. Distribution of geodetic (a) and geologic (b) slip rates as reported in the CAFD.

Our work complements previous efforts by providing an open-access and searchable database that includes an interactive map that is linked to an online database. Database users can generate simple and complex queries to access and view not only fault locations, but also important fault parameters such as slip rates and earthquake history. All data on this website are the product of work in progress and subject to change based on community's feedback and future refinement as more studies become available. An objective of this work is to make fault information available to not only the scientific community, but also to the general public, and to encourage local and international organizations to consider fault location and parameters in their project analysis.

\section{Data sets}

The central Asia Fault Database (CAFD) contains three data sets including fault locations, fault attributes, and seismicity (Table 1). Published maps of faults in the study region identify the location of 1196 Quaternary $(<2.6 \mathrm{Ma})$ traces that define the location of 123 faults that have attributes. Fault attributes (Table 2) are divided into six categories (i.e., identifiers, geographic characteristics, seismic characteristics, structural characteristics, description, and references). Each category contains fields that show relevant fault information. The database fields range from fault name, exposure, and country to Quaternary and geodetic slip rates, earthquake history, geomorphic markers of activity, paleoseismic data, and fault length and sense of motion. Additionally, a brief description and a list of references are provided for each fault. Table 3 provides a more detailed description for each field. Seismicity data include location, magnitude, and depth of over 34000 earthquakes that were recorded throughout the region using global (ANSS ComCat, 2014) and regional (Sippl et al., 2013) seismic networks. All data sets are based on our review of over 250 published papers. The forthcoming sections provide a more detailed description of each data set, and the criteria used for data set selection and evaluation.

\subsection{Fault locations}

Detailed and accurate mapping of fault systems and subsidiary features are essential to understanding of fault characteristics and activity. Precise fault locations can also aid with identification of promising sites for paleoseismic and geomorphic investigations (Zachariasen and Prentice, 2008). Locations of the 1196 fault traces in the current version of CAFD are based on maps and figures that come from 84 published studies. These studies include both those that have broadly defined the location and behavior of Quaternary faults (e.g., northern extension of the Chaman Fault in Afghanistan) and those that more accurately have mapped and described individual strands of fault systems (e.g., Karakoram Fault strands). The latter was chosen for the database when available. The database contains 569 fault traces from the HimaTibetMap of Taylor and Yin (2009), which is an open-source digital database of Quaternary faults located in the Indo-Asian collision zone. The faults taken from the HimaTibetMap are based on field observations and interpretations of satellite images and digital topographic data (Styron et al., 2010; Taylor and Yin, 2009; Taylor et al., 2003) as well as other previously published work.

When digitized data are not available, individual fault traces were digitized from their original sources and at the original publication map scale using the ArcMap software. To digitize a fault, a map is first aligned to available data sets (e.g., country boundaries) and georeferenced using more accurate data layers such as ASTER GDEM2 (30 m resolution digital topography). The faults are digitized and attributed in 
Table 1. Overview of the data sets used in the CAFD.

\begin{tabular}{llll}
\hline Data & \# of entries & Source & Remarks \\
\hline Fault locations & 1196 fault traces & Published literature & Faults with Quaternary traces $(<2.6 \mathrm{Ma})$ \\
Fault attributes & 123 faults & & \\
Earthquakes & 9000 earthquakes & TIPAGE; Sippl et al. (2013) & 08/2008-06/2010 \\
& 25000 earthquakes & ANSS ComCat; ANSS (2014) & 1900-2014 \\
\hline
\end{tabular}

Table 2. Structure of the CAFD and queryable search fields.

\begin{tabular}{llll}
\hline & Database fields & Queryable \\
\hline \multirow{2}{*}{ Identifiers } & Fault ID & - \\
& Name & Yes \\
\hline \multirow{2}{*}{ Geographic characteristics } & Country & Yes \\
& & Physiographic province & Yes \\
\cline { 3 - 4 } & Exposure & - \\
\hline \multirow{2}{*}{ Seismic characteristics } & Slip rates (geologic and geodetic) & Yes \\
& & Historic earthquake & Yes \\
& Geomorphic expression & Yes \\
& Paleoseismic studies & Yes \\
\hline \multirow{2}{*}{ Structural characteristics } & Primary sense of motion & Yes \\
& Strike and dip direction & - \\
& Length & - \\
Description & Brief summary and remarks & - \\
References & Citations & - \\
\hline
\end{tabular}

ArcMap. The attribute table contains information about each fault including its name, sense of movement (if known), references, and other important remarks such as variations in the fault name or location. Fault location accuracy depends on the scale of observation used in previous investigations. Since investigations were conducted at a variety of different scales and methods, some structures are located more precisely than others. For example, Ruleman et al. (2007) mapped features mostly from $90 \mathrm{~m}$ resolution Landsat ETM (Enhanced Thematic Mapper) data at a maximum scale of about 1:50000 ( $\sim 25 \mathrm{~m}$ raster resolution) while Schurr et al. (2014) relied on $1: 200000$ maps ( $\sim 100 \mathrm{~m}$ raster resolution) for their interpretation of Cenozoic faults. To increase location accuracy, Schurr et al. (2014) also used satellite imagery and fieldwork. These examples demonstrate that uncertainties in the positions of each fault in this database are variable, and therefore users are encouraged to consult the original source provided in the comments field within the database for a detailed understanding of the location uncertainties associated with each fault.

In general, the position accuracy for each fault is suitable for visualizing and plotting faults at a regional scale and most likely not suited for site-specific studies without consulting the original study provided in the references. When there are discrepancies in fault locations, we adjusted the position of previously mapped faults to coincide with surface features visible in ASTER GDEM2 data that are indicative of their trace. This is noted in the comment fields of the database. Faults with an undetermined level of Quaternary activity (e.g., Herat Fault in Afghanistan) are included in the database to avoid creating false impressions about seismic hazard and risk in some localities. Finally, Quaternary faults not documented in this study exist and may be active, but are unfortunately not yet documented sufficiently for inclusion in this study.

\subsection{Fault attributes}

All fault parameters used in the database fields (Table 3) are documented from original sources. More specific information about each parameter is reported in the comments field within the database, especially where discrepancies exist. The most common database fields with comments include fault name, exposure level, geodetic and geologic slip rates, and sense of motion. The comments field for fault name explains different names used to refer to the same fault including variations in spelling (e.g., North Pamir Thrust is also referred to as Main Pamir Thrust, Main Alai Thrust, and Pamir Thrust System). Similarly, the fault exposure comments are used for faults with varying levels of surface exposure (e.g., Himalayan Main Frontal Thrust being concealed within the mapping area of Raiverman et al. (1993) but displaying mor- 
Table 3. Description of parameters and fields used in the CAFD.

\begin{tabular}{|c|c|}
\hline Database fields & Description \\
\hline Name & $\begin{array}{l}\text { The most commonly used fault name in the published literature. Name variations and } \\
\text { spelling are included in the comment section. }\end{array}$ \\
\hline Country & Name of countries where the fault trace is located. \\
\hline Physiographical province & $\begin{array}{l}\text { Name of regions with similar terrain and geologic history (e.g., Pamir, Tarim Basin, Alai } \\
\text { Valley). }\end{array}$ \\
\hline Exposure & Fault exposure level (exposed or concealed). \\
\hline Geodetic slip rate $\left(\mathrm{mm} \mathrm{yr}^{-1}\right)$ & $\begin{array}{l}\text { The reported geodetic slip rate as documented in the original studies. It is shown } \\
\text { in } \mathrm{mm} \mathrm{yr}^{-1} \text { and as a minimum-maximum range. Comments specific to the geodetic slip } \\
\text { rate including all reported rates, types, uncertainties, references, as well as methods are } \\
\text { included in the comment section. }\end{array}$ \\
\hline Geologic slip rate $\left(\mathrm{mm} \mathrm{yr}^{-1}\right)$ & $\begin{array}{l}\text { The reported Quaternary slip rate as documented in the original studies. It is shown } \\
\text { in } \mathrm{mm} \mathrm{yr}^{-1} \text { and as a minimum-maximum range. Comments specific to the geologic slip } \\
\text { rate including all reported rates, types, uncertainties, dating methods, and references are } \\
\text { included in the comment section. }\end{array}$ \\
\hline Historic earthquake & $\begin{array}{l}\text { Documented past earthquakes including location, magnitude, timing, related surface fea- } \\
\text { tures (offsets, scarps, etc.), and references. }\end{array}$ \\
\hline Geomorphic expression & $\begin{array}{l}\text { Location and description of fault-related geomorphic markers (e.g., offset or deflected } \\
\text { stream channels, sag ponds, scarps in young alluvium) as well as published analysis, } \\
\text { interpretation, and references. }\end{array}$ \\
\hline Paleoseismic studies & $\begin{array}{l}\text { Location and description of paleoseismic studies and references including trench site lo- } \\
\text { cation and observations. }\end{array}$ \\
\hline Primary sense of motion & $\begin{array}{l}\text { The dominant style of faulting as reported in published literature. Comments specific to } \\
\text { fault motion including changes in style of faulting along the strike as well as other docu- } \\
\text { mented components of movements and references are included in the comment section. }\end{array}$ \\
\hline Dip direction & $\begin{array}{l}\text { Dip direction of the main fault trace or fault zone. Comments specific to dip direction } \\
\text { including reported direction for specific fault traces. }\end{array}$ \\
\hline Strike & $\begin{array}{l}\text { Strike of the main fault trace or fault zone. Comments specific to the strike of the fault } \\
\text { including reported strikes for specific fault traces. }\end{array}$ \\
\hline Length $(\mathrm{km})$ & $\begin{array}{l}\text { Length of the fault trace in kilometers. Comments specific to fault length including length } \\
\text { of studied traces, total fault length, and references are included in the comment section. }\end{array}$ \\
\hline Description & A brief description of the fault and its geologic and tectonic settings. \\
\hline References & References for fault parameters and trace(s) on the interactive map. \\
\hline
\end{tabular}

phology indicative of surface faulting near Chapri Rao and west of the Tamuna River as shown in Wesnousky et al., 1999). Additional data for slip rates such as type, uncertainties and locations are included in the relevant comments fields. Where different types of fault movements are reported for the same structure (e.g., thrust with component of leftlateral shear reported for Oinak-Djar Fault) or when a fault's style of movement changes along its length (e.g., Konar Fault showing a progressively greater component of thrust faulting northeastward), the comments field reflects this information. Comments fields can also include references used for an entry in a database field. Important fault attributes such as Qua- ternary and geodetic slip rates are discussed in more detail below.

\subsection{Slip rates}

Slip rate data are important in constraining seismic hazard as they are used to estimate the rate of earthquakes on known faults. The CAFD documents both Quaternary and geodetic slip rates for faults. Quaternary slip rates are often used in seismic hazard models as these values are thought to better represent deformation rates appropriate for hazard models (Dawson and Weldon, 2013). Where these rates are lacking or inaccurate, particularly in locations with no evidence for 
Table 4. Summary of Quaternary and geodetic fault slip rates. All rates are estimates and demonstrate the ranges of reported slip rate values for each fault. Fault labels are as in Fig. 8.

\begin{tabular}{llll}
\hline Fault label & Fault name & $\begin{array}{l}\text { Geologic slip rate } \\
\left(\mathrm{mm} \mathrm{yr}^{-1}\right)\end{array}$ & $\begin{array}{l}\text { Geodetic slip rate } \\
\left(\mathrm{mm} \mathrm{yr}^{-1}\right)\end{array}$ \\
\hline ATF & Altyn Tagh fault & $2->20$ & $6-11$ \\
BMF & Black Mango fault & 10 & 14 \\
CF & Chaman fault & $25-35$ & $8-17$ \\
DKF & Darvaz-Karakul fault & $10-15$ & 10 \\
HRF & Herat fault & $2-3$ & $<2$ \\
HF & Haiyuan fault & $3-19$ & $4-8$ \\
KF & Karakorum fault & $4-32$ & $1-11$ \\
KKF & Karakax fault & 20 & $5-7$ \\
KLF & Kunlun fault & $2-13$ & $1-12$ \\
LMT & Longman Shan thrust belt & $<1$ & $<1-4$ \\
MFT & Main Frontal thrust & $6.3-21$ & $13-20$ \\
MJF & Muji fault & 4.5 & $4-5$ \\
MPT & Main Pamir thrust & $2-6$ & $10-15$ \\
PFT & Pamir Frontal thrust & $6-7$ & $6-9$ \\
RRF & Red River fault & $2-3$ & $1-2$ \\
SF & Sagaing fault & $10-23$ & 18 \\
TF & Talas-Fergana fault & $5-19$ & $<1-3$ \\
XXF & Xianshuihe-Xiaojiang fault system & $5-18$ & $10-11$ \\
\hline
\end{tabular}

old or recent earthquakes, geodetic rates from GPS or InSAR are used to determine present-day deformation rates for faults. These rates include interseismic, coseismic, and postseismic motions, yielding information that can help with identification of locked fault traces or creeping faults.

In the database, Quaternary and geodetic slip rates are reported in millimeters per year, showing minimum and maximum reported values from published literature. These values are reported as slip rates in referenced study and include slip components that reflect the predominant sense of slip for faults. Slip rate data are reported in a variety of ways in published literature (e.g., horizontal, vertical, or dip-slip). The database reports what was originally documented in the published study. This as well as other supporting data such as site location, offset feature, dating method, time interval over which the rate was calculated, and reported uncertainties are shown in the comments section of the database.

Figure 2 shows the distribution of geodetic and Quaternary slip rates for faults included in the database. Geodetic slip rates are reported for 26 faults, with values ranging from $<5 \mathrm{~mm} \mathrm{yr}^{-1}$ to $<30 \mathrm{~mm} \mathrm{yr}^{-1}$, with most rates reported as maximums with values between 10 and $15 \mathrm{~mm} \mathrm{yr}^{-1}$, and as minimums with values $<5 \mathrm{~mm} \mathrm{yr}^{-1}$ (Fig. 2a). Quaternary slip rates reported for 38 faults show values ranging from $<5$ to $40 \mathrm{~mm} \mathrm{yr}^{-1}$, with most rates reported as minimum with values $<5 \mathrm{~mm} \mathrm{yr}^{-1}$ (Fig. 2b). There are only 18 faults that have both Quaternary and geodetic slip rates (Table 4). Corresponding uncertainties in fault slip rates as well as other supporting data such as site location, offset geomorphic feature, and dating method for offset features are reported from the original studies and are included in the comments fields of the database.

\subsection{Seismicity}

The earthquakes in the current version of CAFD include over 25000 events from the Advance National Seismic System Comprehensive Catalog (ANSS ComCat). These events were recorded by over 150 seismic stations distributed globally over 80 countries as part of the Global Seismographic Network (Gee and Leith, 2011). The events cover a period from 1900 to 2014. The magnitude for each event is calculated using several different methods, depending upon the type of earthquake, the amount of energy released, and the policies of the authoritative seismic network. The position uncertainty of a hypocenter location of an event in the ANSS ComCat is defined by its epicenter and focal depth, and is estimated to be tens of kilometers. Since the accuracy in determining the epicenter location, depth, and size of an earthquake is a function of the geometry and density of seismograph networks and available seismic data (Husen and Hardebeck, 2010), smaller-sized events $(M<5)$ in the database must be treated with caution as they are unlikely to have been accurately located. The ANSS ComCat is particularly useful for areas with no local network, and is commonly used in studies concerning active tectonics and seismicity in the India-Eurasia collision zone. However, users should be aware that the ANSS ComCat is a composite catalog, based on earthquake catalogs contributed by its member networks, and is not uniform in its coverage and magnitude completeness. 

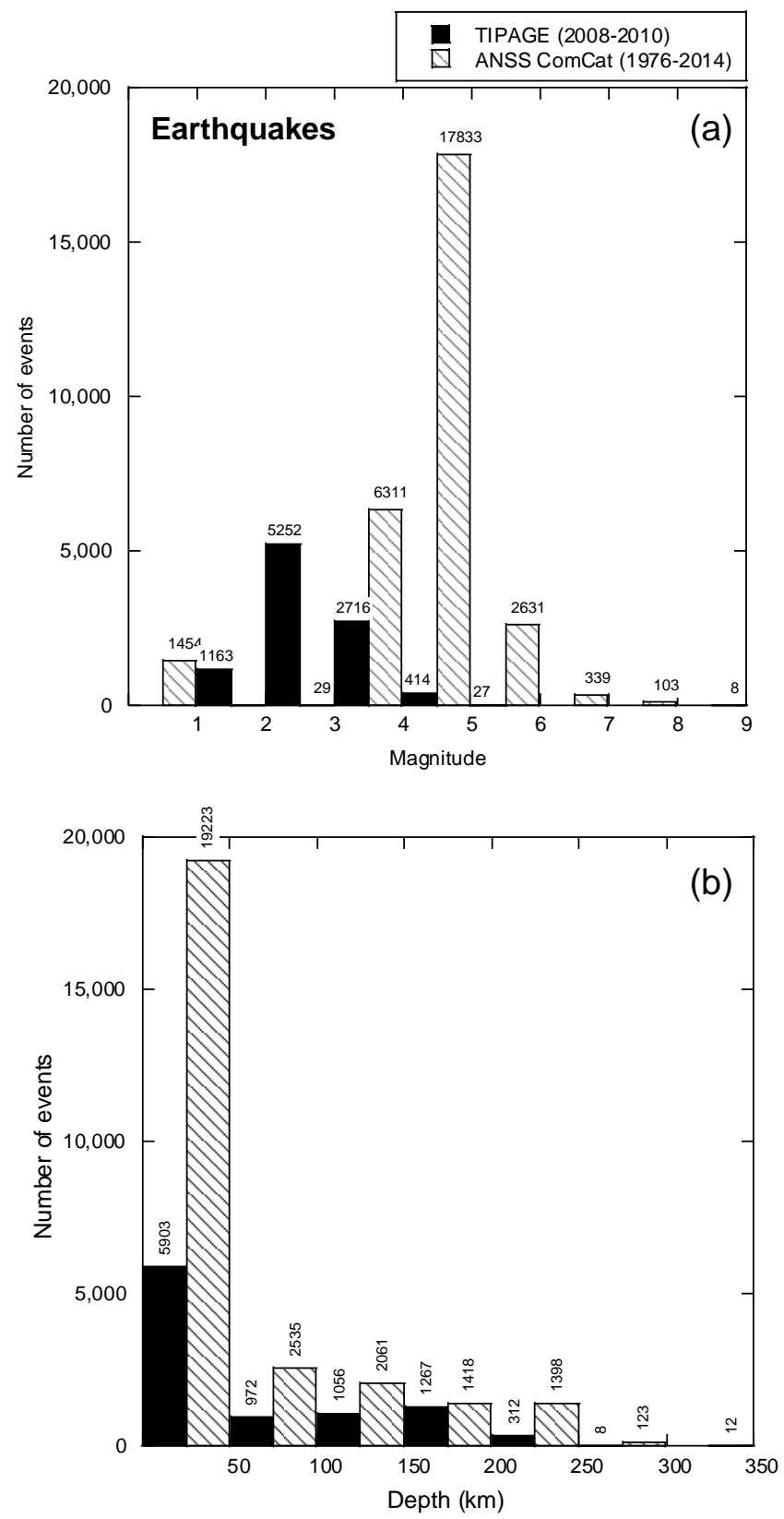

Figure 3. Earthquake distribution based on magnitudes (a) and depths (b) from global (ANSS ComCat) and regional (TIPAGE) catalogs.

The ANSS global catalog is complemented by events from local networks and other temporary station deployments in the Pamir, Hindu Kush, and South Tien Shan. The database displays over 9000 events from the local TIPAGE (TIen Shan PAmir GEodynamic Program) catalog. These events were detected by a network of 40 seismic stations in southern Kyrgyzstan and eastern Tajikistan over a period of 2 years from August 2008 to June 2010. Sippl et al. (2013) used a probabilistic earthquake relocation method (Lomax et al., 2000) to measure absolute location errors. They estimated mean location uncertainties in longitudinal, latitudinal, and vertical directions, calculated for bins in different depth layers. Their results show vertical errors being larger than horizontal errors for all events, with horizontal errors lower than $7.5 \mathrm{~km}$ and vertical errors lower than $15 \mathrm{~km}$ throughout the Pamir.

In the database, all earthquakes are displayed based on their size (i.e., below or above magnitude 5) and depth (i.e., below or above $70 \mathrm{~km}$ depth). Events below magnitude 5 are considered to have intensity values of $\mathrm{I}-\mathrm{V}$ on the Modified Mercalli Intensity Scale used by the United States Geological Survey, indicating micro to light shaking effects. Events over magnitude 5 are given intensity values of VIVIII or above indicating moderate to great shaking effects that are felt over large areas and causing damage to structures. Events between 0 and $70 \mathrm{~km}$ are considered to be shallow while those above $70 \mathrm{~km}$ are intermediate or deep events. The earthquake locations are indicated by circles, each representing an earthquake's epicenter. Figure 3 shows the distribution of earthquakes from both catalogs based on magnitude and depth. Most events in both catalogs have magnitudes below 5 (Fig. 3a). Events with magnitudes between 1 and 3 are captured by the TIPAGE regional network and events with magnitudes above 5 are captured mostly by the ANSS global catalog. By combining these data sets, the database provides an improved catalog of past event magnitudes. Most events in both catalogs show depths of up to $50 \mathrm{~km}$ below the surface (Fig. 3b) with deeper events $(>250 \mathrm{~km})$ represented by the ANSS global catalog only which might be due to larger uncertainties in the calculated depth for events from the ANSS catalog. In the east of Alai valley and within the Pamir thrust system, the 2008 Nura earthquake and its aftershock series ( 3000 events) are captured by the TIPAGE catalog, and are included in the database in different colors (Fig. 5b) to allow users to differentiate them from background seismicity in the Alai valley.

\section{Database construction}

The CAFD construction follows four steps (Fig. 4). First, previously published literature and databases related to Quaternary faulting in central Asia were compiled and reviewed. Fault trace data were prepared in the ArcMap software, and used to populate tables created in a MySQL database using an open source, web-based application called phpMyAdmin (https://www.phpmyadmin.net/). The MySQL database is composed of data tables that can be queried. The fault location table was created to store geographic coordinates (i.e., latitude, longitude) of points that made up a fault trace. The fault attribute table was created to organize attribute information shown in Tables 2 and 3. To link the fault location table to the fault attribute table, a unique identification number was assigned to each fault and used in both tables. Using PHP scripting (http://www.php.net/), the fault loca- 


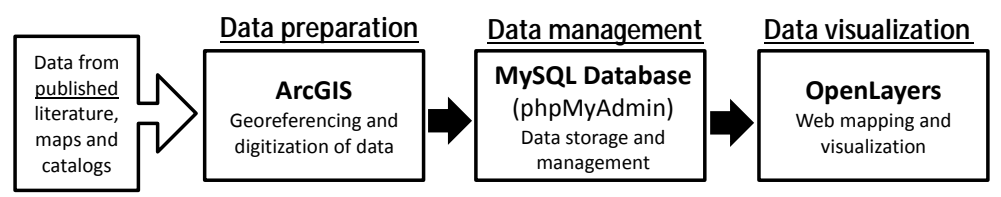

Figure 4. Flowchart of the process for the CAFD development.

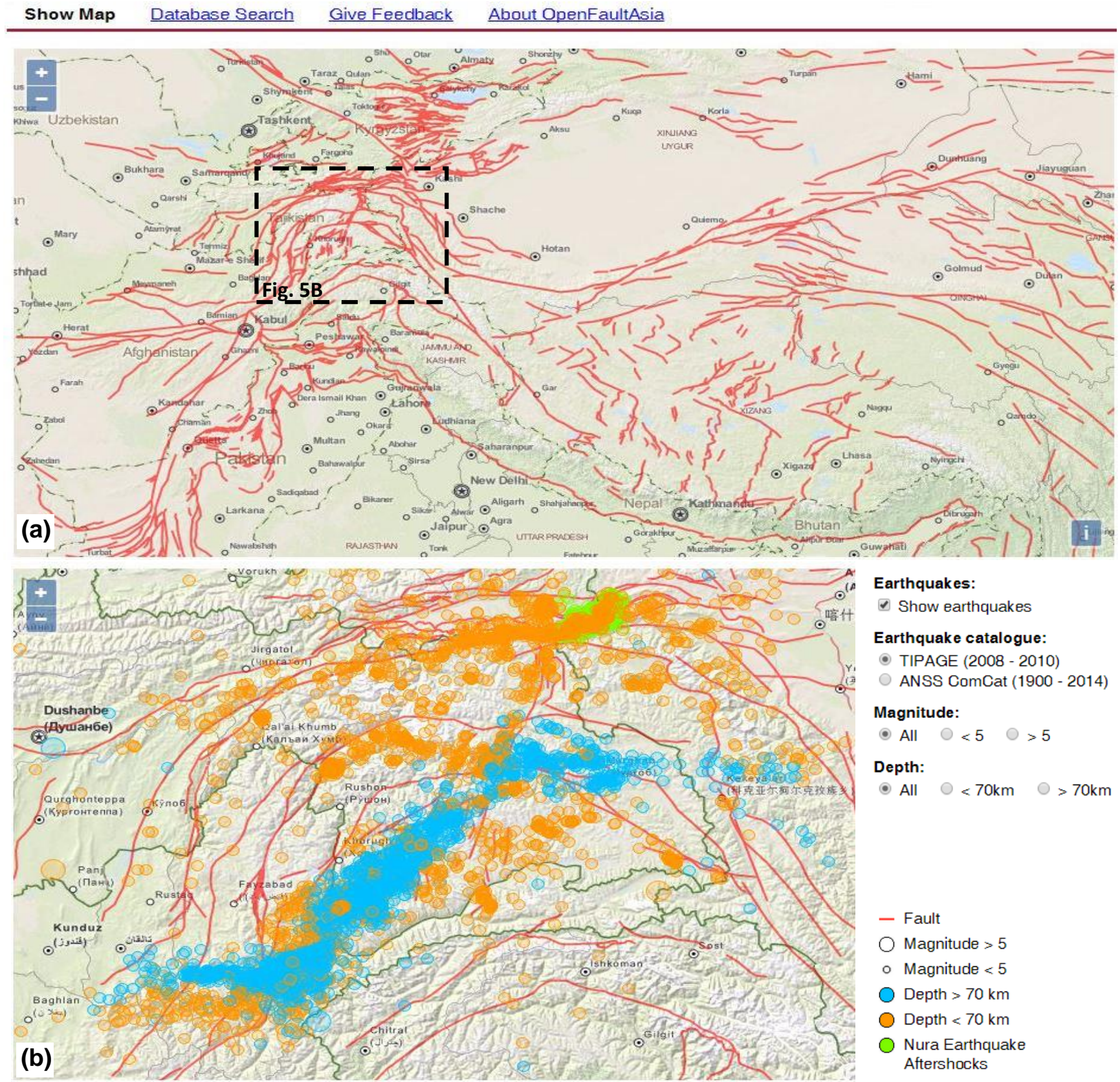

Figure 5. The database interface includes an interactive fault map with faults shown in red (a). Example of a map display with earthquake data set from Sippl et al. (2013) is shown for the Pamir and the Hindu Kush regions (b). Black dashed box in (a) shows the map extent displayed in (b). 


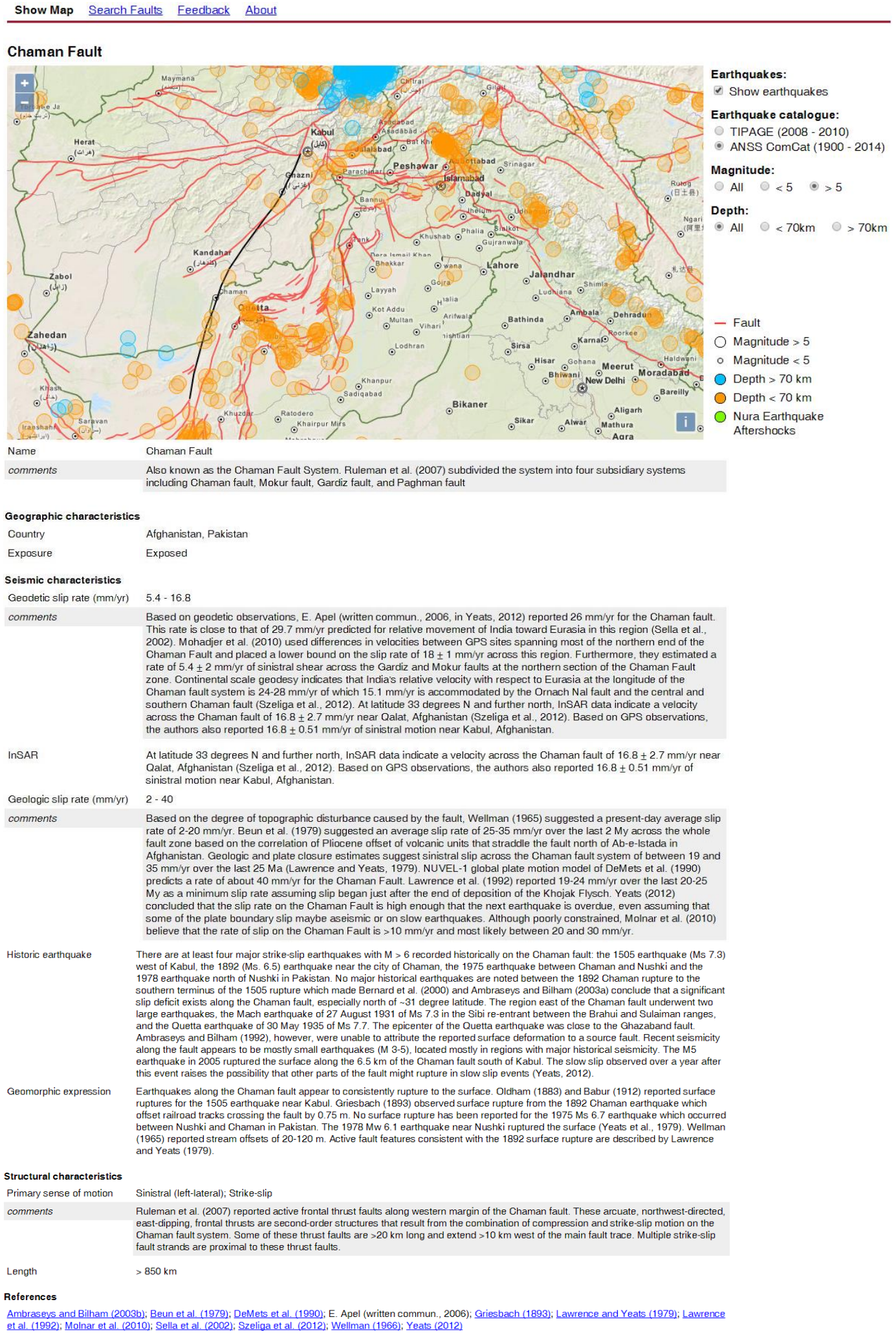

Figure 6. An example of a fault information page. The location map on top shows the selected fault in black (i.e., Chaman Fault). The fault description appears below the map. The description is organized into three distinct sections (i.e., geographic, seismic, and structural characteristics) with references linked to Google Scholar. Users can display earthquake data to visualize recorded seismicity in relation to the selected structure. 
Show Map Search Faults Feedback About

Fill in one or more fields and start search. The search tool permits searches on fault name and location. Users can also limit their search results by making queries on seismic and structural characteristics of faults.

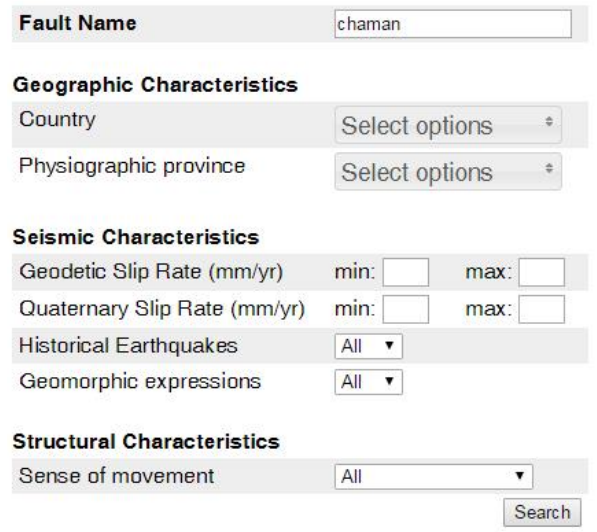

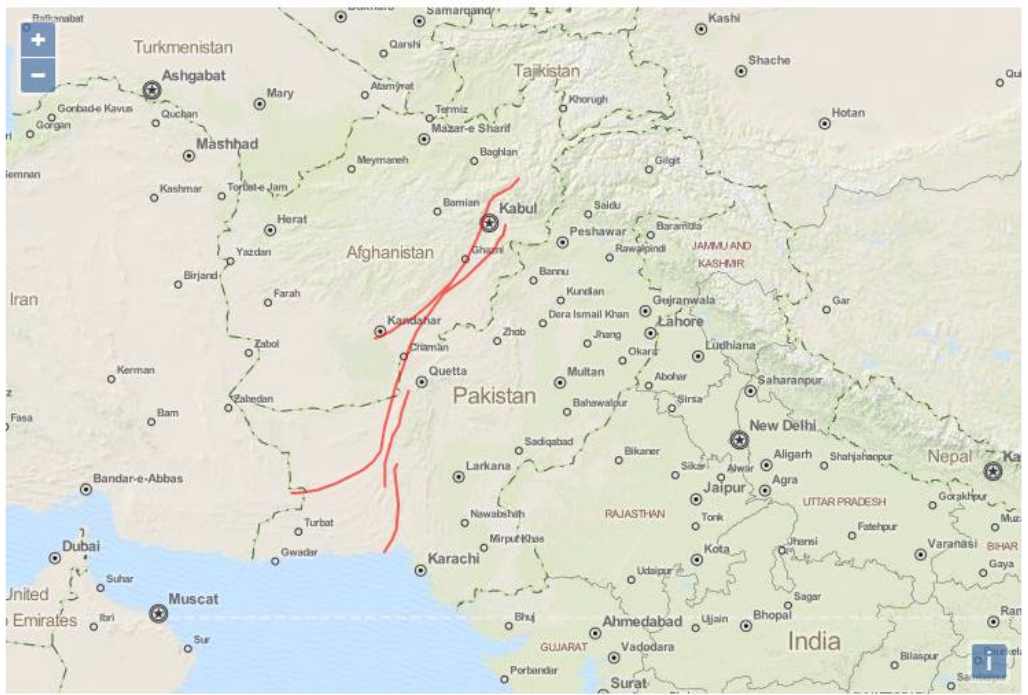

Bella-Chaman-Kurram Fault Zone

Chaman Fault

Gardiz Fault

Ghazaband Fault

Mokur Fault

Ornach-Nal Fault

Paghman Fault

Panjshir Fault

Siahan Fault

Figure 7. The database search tool allows users to search and sort fault information on a variety of fields. The above example shows search results for the Chaman Fault. The search yields results relevant to the Chaman fault including faults that are considered to be part of its extensions. These results are shown as a list and can be visualized on the map. Fault names and locations are linked to relevant fault information page.

tion and attribute data were then extracted from these tables for display in an open source web-mapping application called OpenLayers (http://openlayers.org/). To display earthquake data, a table was created in the database to store location coordinates, depth, magnitude, and source values. These data were similarly extracted from the database for display in OpenLayers. The reference table was created and displayed similarly, containing fields such as fault identification number, citation appearance, and manuscript title. This table was used to generate an automated query in Google Scholar by clicking on a citation listed for a fault. All raw data in the CAFD are accessible for viewing and download via http://www.geo.uni-tuebingen.de/faults/ and the supplementary information accompanying this article. Users who download the data are encouraged to regularly check for new entries or subscribe to the email list server for this database.

\section{User interface}

The CAFD online interface includes an interactive fault map and a search tool. The fault map displays the locations of Quaternary faults (Fig. 5a) and includes a user-controlled earthquake data layer (Fig. 5b) that organizes data by magnitude, depth, and source. Clicking on a fault trace brings up an information page (Fig. 6) that is linked to the fault attribute and reference tables in the database, displaying relevant information organized by database fields (Table 3). The information page also contains a location map that highlights the fault location.

The search tool (Fig. 7) allows users to query the database using specific fields. Table 2 shows fields that are queryable. The queries can be simple (e.g., fault name or country location) or more complex (e.g., sorted by slip rate, sense of motion, earthquake history, etc.). A query can generate results (i.e., fault names shown in a list and on a map) that are linked to fault information and location pages described above. 


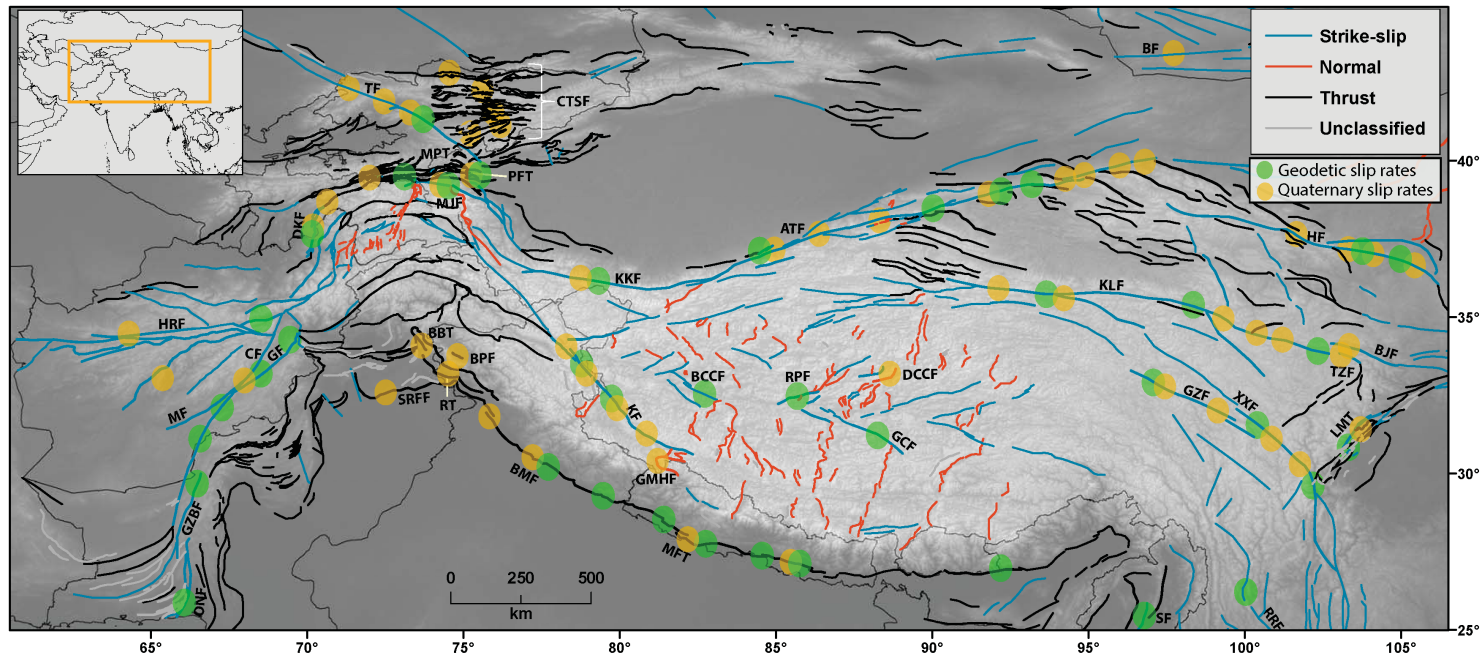

Figure 8. Map showing the locations of major Quaternary faults. Fault lines are color-coded based on their sense of movement. Locations of reported slip rates are marked with colored circles. Abbreviations of fault names: ATF: Altyn Tagh fault; BBT: Balakot-Bagh Thrust; BCCF: Bue Co Conjugate Fault system; BF: Bogd Fault; BPF: Balapora Fault; BJF: Bailong Jiang Fault system; BMF: Black Mango Fault; CF: Chaman Fault; CTSF: central Tien Shan faults (including Issyk-Ata, Akchop Hills, South Kochkor, Kadjerty, central Naryn, OinakDjar, North and South Kyrkungey faults); DCCF: Dong Co Conjugate Fault system; DKF: Darvaz-Karakul Fault; GCF: Gyaring Co Fault; GF: Gardiz Fault; GMHF: Gurla Mandhata-Humla Fault system; GZBF: Ghazaband Fault; GZF: Ganzi Fault; HF: Haiyuan Fault; HRF: Herat Fault; KF: Karakorum Fault; KKF: Karakax Fault; KLF: Kunlun Fault; LMT: Longmen Shan Thrust belt; MF: Mokur Fault; MFT: Main Frontal Thrust; MJF: Muji Fault; MPT: Pamir Main Thrust; ONF: Ornach-Nal Fault; PFT: Pamir Frontal Thrust; RPF: Riganpei Co Fault; RRF: Red River Fault; RT: Riassi Thrust; SF: Sagaing Fault; SRFF: Salt Range Front Fault; TF: Talas-Fergana Fault; TZF: Tazang Fault; XXF: Xianshuihe-Xiaojiang Fault system. The coordinate system for the map is Geographic (WGS84), with topography from ASTER GDEM2.

\section{Database completeness}

The main objective of the CAFD is to provide a publicly accessible central source of information related to Quaternary faults in central Asia and to set a framework for future data additions and research. Similar to the HimaTibetMap of Taylor and Yin (2009), the data in the CAFD are drawn from published manuscripts that are based on limited studies, and require continual evaluation as newer data become available. For example, a large number of faults lack geodetic or Quaternary slip rates, and most faults contain no paleoseismic information.

Although the database has implications for seismic hazard studies in central Asia, it is impractical to construct a hazard map based solely on the information provided here. The database contains Quaternary faults with surface traces, providing only a two-dimensional representation of faults and potentially leaving out active nonplanar faults and those that are concealed beneath the Earth's surface. The accuracy of fault position data for faults with surface traces also depends on mapping methods and scales of observations, which vary significantly between individual studies. Similarly, the accuracy of fault attributes can vary between individual studies. For example, fault slip rate measurements are based on estimates of displacements along faults and age measurements of offset landforms, both of which contain uncertainties that are obtained and reported differently across referenced studies. Database users, therefore, are encouraged to refer to comments fields in the database for more information about reported values, and to references cited for original work. These limitations combined with short seismological records and insufficient information about earthquake shaking intensities are a great challenge to mapping hazards in the region. A more complete hazard assessment process should consider long-term earthquake history of faults (available from paleoseismic data), GPS velocity data showing present-day strain accumulation across active structures, and more accurate mapping of Quaternary faults, especially those with no clear surface expression (e.g., blind faults).

\subsection{Data gaps}

At its current stage, the database guides future research by identifying areas where further investigations are needed. Figure 8 shows the locations of Quaternary faults as documented in the database, color-coded based on their sense of motion. Although the sense of motion for most active structures is well-characterized, slip rates for most remain unknown. Slip rates are reported for a total of 64 faults in the current version of the CAFD. This includes 26 geodetic and 38 Quaternary rates. Only 18 faults, however, have both types of slip rates. These faults are often $>1000 \mathrm{~km}$ long and bound 
major topographic features (e.g., the $\sim 1200 \mathrm{~km}$-long AltynTagh Fault at the northern margin of the Tibetan Plateau, the $>1500 \mathrm{~km}$-long Main Frontal Thrust system along the Himalaya, and the $\sim 1000 \mathrm{~km}$-long Chaman Fault system that bounds the western edge of the Indian Plate). Some faults such as the Altyn Tagh, Kunlun, and Karakoram faults have Quaternary slip rates that are constrained by several studies in different localities along the fault trace. Other fault zones such as those in northwest of Tibet and the central Pamir, require further investigation. Quaternary slip rates in this region are often qualitative, associated with large uncertainty (e.g., the Darvaz-Karakul Fault) or disagree with GPS measurements (e.g., the Talas Fergana and Karakorum faults).

The northern and western margins of the Pamir have geodetic relative velocities of $13-15$ and $10 \mathrm{~mm} \mathrm{yr}^{-1}$ respectively. Quaternary slip rates for these areas are only available for the central segment of the Pamir thrust system. Therefore, where and how these motions are accommodated remains poorly understood. Unlike central Tibet where Quaternary and geodetic slip rates are known for several fault systems (e.g., Bue Co and Dong Co conjugate fault systems), the faults located in the interior of the Pamir lack Quaternary rates despite accommodating $5-10 \mathrm{~mm} \mathrm{yr}^{-1}$ of east-west extension measured by GPS geodesy (Ischuk et al., 2013).

Further south, few geologic and geodetic constraints exist on slip rates for faults in Afghanistan and the Baluchistan province of Pakistan. The only available geodetic rates are for the Chaman Fault system and its northern (e.g., Gardiz and Mokur faults) and southern (e.g., Ornach-Nal and Ghazaband faults) extensions. Despite constraints placed by deformation models on the present-day kinematics of regions south and west of the western Himalayan Syntaxis (e.g., the Sulaiman Lobe and Range), it remains unclear exactly how and where this deformation is accommodated. The database highlights regions and fault systems that have wellconstrained slip rate data and those that lack such data, and hence, can guide future research by identifying where data gaps exist.

\section{Database maintenance}

All domain and web hosting services are provided and maintained by the University of Tübingen, Germany. The content update is a collaborative process which includes content identification, content review, and database update. Content identification is done by a group of experts who are selected and contacted semiannually for published research results. A larger number of potential experts and users are also contacted using selected list servers. Users can submit new content directly via the website email (cafd@geo.unituebingen.de) or by completing the feedback form on the website. Once content is submitted, it is checked for accuracy and consistency by the CAFD review team before being posted on the website.

\section{Conclusion}

The central Asia fault database contains 1196 fault traces that can be viewed, searched, and downloaded for plotting in ArcGIS and other programs. Fault parameters and descriptions for over 123 Quaternary faults are extracted and documented in the database and can be searched and viewed by users. Over 34000 earthquakes from global and local catalogs are included in data layers to explore the relationship between seismicity and Quaternary faulting. This database is the first publicly available digital repository for Quaternary faults of central Asia and the surrounding region with search capabilities that allow users sort and view critical fault information on a variety of fields (e.g., geographic, seismic, geomorphic, structural). This information is critical for current and future analysis of earthquake hazard studies in the region. The database is designed to fulfill the needs of a wide range of users ranging from the science community to the general public and non-academic users. The database will be continuously updated as new information becomes available and as users identify data that have been overlooked using a webbased discussion forum or contacting the authors directly.

\section{The Supplement related to this article is available online at doi:10.5194/nhess-16-529-2016-supplement.}

Acknowledgements. We thank Steve Thompson, Ray Weldon, Mike Taylor, Richard Styron, Cal Ruleman, Bernd Schurr, and Richard Gloaguen for generously sharing their data. We also thank Peter Molnar, Roger Bilham, Kathy Haller, and Walter Mooney for their helpful discussions. Saeid Mohadjer, Faheem Merchant, Stéphane Henroid, Cassidy Jay, and Najibullah Kakar provided thoughtful feedback on website design, usability and content. Roland Schraven assisted with preparing earthquake and topography data used in this manuscript. In its early stage, this project benefited immensely from fruitful discussions with Michael Märker, Jason Barnes, and Lothar Ratschbacher. James Daniell, Kathy Haller, and Bernd Schurr are thanked for reviewing our paper and their constructive comments. This project was supported by the CAME project bundle TIPTIMON of the German Federal Ministry of Education and Research grant BMBF 03G0809 (to T. A. Ehlers) and the German Science Foundation grant STU 525/1-1 (to K. Stübner).

Edited by: O. Katz

Reviewed by: K. Haller, J. E. Daniell, and B. Schurr

\section{References}

Abdrakhmatov, K. Y., Aldazhanov, S. A., Hager, B. H., Hamburger, M. W., Herring, T. A., Kalabaev, K. B., Makarov, V. I., Molnar, P., Panasyuk, S. V., Prilepin, M. T., Reilinger, R. E., Sadybakasov, I. S., Souter, B. J., Trapeznikov, Y. A., Tsurkov, V. Y., 
and Zubovich, A. V.: Relatively recent construction of the Tien Shan inferred from GPS, Nature, 384, 450-453, 1996.

Advance National Seismic System Comprehensive Catalog (ANSS ComCat): available at http://earthquake.usgs.gov/earthquakes/ search/, last access: December 2014.

Avouac, J. P.: Dynamic processes in extensional and compressional settings - Mountain building from earthquakes to geological deformation, in: Treatise on Geophysics, edited by: Schubert, G., Elsevier, Amsterdam, 377-439, 2007.

Bendick, R., Bilham, R., Khan, M. A., and Khan, S. F.: Slip on active wedge thrust from geodetic observations of the 8 October 2005 Kashmir earthquake, Geology, 35, 267-270, 2007.

Bendick, R., Khan, S. F., Burgmann, R., Jouanne, F., Banerjee, P., Khan, M. A., and Bilham, R.: Postseismic relaxation in Kashmir shows lateral variations in crustal architecture and materials, Geophys. Res. Lett., 42, 4375-4383, 2015.

Chevalier, M.L., Tapponnier, P., Van der Woerd, J., Ryerson, F.J.,Finkel, R.C., and Li, H.: Spatially constant slip rate along the southern segment of the Karakorum fault since $200 \mathrm{ka}$, Tectonophysics, 530-531, 152-179, 2012.

Dawson, T. E. and Weldon II, R. J.: Appendix B: Geologic slip-rate data and geologic deformation model, U.S. Geol. Surv. OpenFile Rept. 2013-1165-B, and California Geol. Surv. Special Rept. 228-B, 2013.

Feld, C., Haberland, C., Schurr, Bernd, Sippl, C., Wetzel, H, Roessner, S., Ickrath, M., Abdybachaev, U., and Orunbaev, S.: Seismotectonic study of the Fergana Region (Southern Kyrgyzstan): distribution and kinematics of local seismicity, Earth Plan. Space, 67, 1-13, 2015

Field, E. H., Biasi, G. P., Dawson, T. E., Felzer, K. R., Jackson, D. D., Johnson, K. M., Jordan, T. H., Madden, C., Michael, A. J., Milner, K. R., Page, M. T., Parsons, T., Powers, P. M., Shaw, B. E., Thatcher, W. R., Weldon II, R. J., and Zeng, Y.: Uniform California earthquake rupture forecast, version 3 (UCERF3) - The Time-independent model: U.S. Geological Survey Open-File Report 2013-1165, 97 pp., California Geological Survey Special Report 228, and Southern California Earthquake Center Publication 1792, available at: http://pubs.usgs.gov/of/2013/1165/, last access: June 2015, 2013.

Gee, L. S. and Leith, W. S.: The Global Seismographic Network: United States Geological Survey, Fact Sheet 2011-3021, available at http://pubs.usgs.gov/fs/2011/3021/, last access: May 2015,2011

Haberland, C., Abdybachaev, U., Schurr, B., Wetzel, H.-U., Roessner, S., Sarnagoev, A., Orunbaev, S., and Janssen, C.: Landslides in southern Kyrgyzstan: understanding tectonic controls, Eos T. Am. Geophys. Un., 92, 169-170, 2011.

He, W., Xiong, Z., Yuan, D. Y., Ge, W. P., and Liu, X. W.: Paleoearthquake study on the Maqu fault of East Kunlun Active Fault, Earthquake Res. China, 22, 126-133, 2007.

Hodges, K.: Tectonics of the Himalaya and southern Tibet from two perspectives, Geol. Soc. Am. Bull., 112, 324-350, 2000.

Husen, S. and Hardebeck, J. L.: Earthquake location accuracy, Community Online Resources for Statistical Seismicity Analysis (CORSSA), version 1, doi:10.5078/corssa-55815573, available at http://www.corssa.org/articles/themeiv/husenhardebeck, last access: June 2015, 2010.
Ioffe, A., Govorova, N., Volchkova, G., and Trifonov, R.: Database of active faults for the USSR area, Geoinformatics, 4, 289-290, 1993.

Ioffe, A. I. and Kozhurin, A. I.: Database of active faults of Eurasia, J. Earthquake Pred. Res., 5, 431-435, 1996.

Ischuk, A., Bendick, R., Rybin, R., Molnar, P., Khan, S. F., Kuzikov, S., Mohadjer, S., Saydullaev, U., Ilyasova, Z., Schelochkov, G., and Zubovich, A. V.: Kinematics of the Pamir and Hindu Kush regions from GPS geodesy, J. Geophys. Res.-Sol. Ea., 118, 1-9, 2013.

Kaneda, H., Nakata, T., Tsutsumi, H., Kondo, H., Sugito, N., Awata, Y., Akhtar, S. S., Majid, A., Khattak, W., Awan, A. A., Yeats, R. S., Hussain, A., Ashraf, M., Wesnousky, S. G., and Kausar, A. B.: Surface Rupture of the 2005 Kashmir, Pakistan, Earthquake and Its Active Tectonic Implications, B. Seismol. Soc. Am., 98, 521-557, doi:10.1785/0120070073, 2008.

Korjenkov, A. M., Rust, D., Tibaldi, A., and Abdieva, S. V.: Parameters of the Strong Paleoearthquakes Along the Talas-Fergana Fault, the Kyrgyz Tien Shan, Earthquake Research and Analysis - Seismology, Seismotectonic and Earthquake Geology, edited by: D’Amico, S., InTech, Croatia, 2012.

Kumar, S., Wesnousky, S. G., Rockwell, T. K., Ragona, D., Thakur, V. C., and Seitz, G. G.: Earthquake recurrence and rupture dynamics of Himalayan Frontal Thrust, India, Science, 294, 23282332, 2001.

Kumar, S., Wesnousky, S. G., Rockwell, T. K., Briggs, R W., Thakur, V. C., and Jayangondaperumal, R.: Paleoseismic evidence of great surface rupture earthquakes along the Indian Himalaya, J. Geophys. Res.-Sol. Ea., 111, B03304, doi:10.1029/2004JB003309, 2006

Lavé, J., Yule, D., Sapkota, S., Basant, K., Madden, C., Attal, M., and Pandey, R.: Evidence for a Great Medieval Earthquake ( 1100 A.D.) in the Central Himalayas, Nepal, Science, 307, 1302-1305, doi:10.1126/science.1104804, 2005.

Lomax, A., Virieux, J., Volant, P., and Berge, C.: Probabilistic earthquake location in 3D and layered models: Introduction of a Metropolis-Gibbs method and comparison with linear locations, in: Advances in Seismic Event Location, edited by: Thurber, C. and Rabinowitz, N., Kluwer, Amsterdam, 101-134, 2000.

Mechie, J., Yuan, X., Schurr, B., Schneider, F., Sippl, C. Ratschbacher, L., Minaev, V., Gadoev, M., Oimahmadov, I., Abdybachaev, U., Moldobekov, B., Orunbaev, S., and Negmatullaev, S.: Crustal and uppermost mantle velocity structure along a profile across the Pamir and southern Tien Shan as derived from project TIPAGE wide-angle seismic data, Geophys. J. Int., 188, 385-407, 2012.

Mellors, R. J., Pavlis, G. L., Hamburger, M. W., Al-shukri, H. J., and Lukk, A. A.: Evidence for a high velocity slab associated with the Hindu Kush seismic zone, J. Geophys. Res.-Sol. Ea., 100, 4067-4078, 1995.

Mohadjer, S., Bendick, R., Ischuk, A., Kuzikov, S., Kostuk, A., Saydullaev, U., Lodi, S., Kakar, D. M., Wasy, A., Khan, M. A., Molnar, P., Bilham, R., and Zubovich, A. V.: Partitioning of India-Eurasia convergence in the Pamir-Hindu Kush from GPS measurements, Geophys. Res. Lett., 37, L04305, doi:10.1029/2009GL041737, 2010.

Plesch, A., Shaw, J. H., Benson, C., Bryant, W. A., Carena, S., Cooke, M., Dolan, J., Fuis, G., Gath, E., Grant, L., Hauksson, E., Jordan, T., Kamerling, M., Legg, M., Lindvall, S., Magis- 
trale, H., Nicholson, C., Niemi, N., Oskin, M., Perry, S., Planansky, G., Rockwell, T., Shearer, P., Sorlien, C., Süss, M. P., Suppe, J., Treiman, J., and Yeats, R.: Community Fault Model (CFM) for Southern California, B. Seismol. Soc. Am., 97, 1793-1802, 2007.

Raiverman, V., Srivastava, A. K., and Prasad, D. N.: On the Foothill Thrust of northwestern Himalaya, J. Himal. Geol., 4, 237-256, 1993.

Ran, Y., Chen, L., Chen, J., Wang, H., Chen, G, Yin, J., Shi, X., Li, $\mathrm{C}$., and $\mathrm{Xu}, \mathrm{X}$.: Paleoseismic evidence and repeat time of large earthquakes at three sites along the Longmenshan fault zone, Tectonophysics, 491, 141-153, 2010.

Reigber, C., Michel, G. W., Galas, R., Angermann, D., Klotz, J., Chen, J. Y., Papschev, A., Arslanov, R., Tzurkov, V. E., and Ishanov, M. C.: New space geodetic constraints on the distribution of deformation in Central Asia, Earth Planet. Sci. Lett., 191, 157$165,2001$.

Robinson, A. C.: Geologic offsets across the northern Karakorum fault: Implications for its role and terrane correlations in the western Himalayan-Tibetan orogen, Earth Planet. Sci. Lett., 279, 123-130, 2009.

Ruleman, C. A., Crone, A. J., Machette, M. N., Haller, K. M., and Rukstales, K. S.: Map and Database of Probable and Possible Quaternary Faults in Afghanistan, United States Geological Survey Open-File Report, 2007-1103, available at: http://pubs.usgs. gov/of/2007/1103/ (last access: July 2015), 2007.

Schiffman, C., Bali, B. S., Szeliga, W., and Bilham, R.: Seismic slip deficit in the Kashmir Himalaya from GPS observations, Geophys. Res. Lett., 40, 5642-5645, 2013.

Schneider, F. M., Yuan, X., Schurr, B., Mechie, J., Sippl, C., Haberland, C., Minaev, V., Oimahmadov, I., Gadoev, M., Radjabov, N., Abdybachaev, U., Orunbaev, S., and Negmatullaev, S.: Seismic imaging of subducting continental lower crust beneath the Pamir, Earth Planet. Sci. Lett., 375, 101-112, 2013.

Schurr, B., Ratschbacher, L., Sippl, C., Gloaguen, R., Yuan, X., and Mechie J.: Seismotectonics of the Pamir, Tectonics, 33, 15011518, 2014.

Sippl, C., Schurr, B., Yuan, X., Mechie, J., Schneider, F. M., Gadoev, M., Orunbaev, S., Oimahmadov, I., Haberland, C., Abdybachaev, U., Minaev, V., Negmatullaev, S., and Radjabov, N.: Geometry of the Pamir-Hindu Kush intermediate-depth earthquake zone from local seismic data, J. Geophys. Res.-Sol. Ea., 118, 1438-1457, 2013.

Strecker, M. R., Hilley, G. E., Arrowsmith, J. R., and Coutand, I.: Differential structural and geomorphic mountain-front evolution in an active continental collision zone: the northwest Pamir, southern Kyrgyzstan, Geol. Soc. Am. Bull., 115, 166-181, 2003.

Styron, R., Taylor, M., and Okoronkwo, K.: Database of Active Structures From the Indo-Asian Collision, Eos T. Am. Geophys. Un., 91, 181-182, 2010.

Tapponnier, P., Ryersonb, F. J., Van der Woerda, J., Mériauxa, A. S., and Lasserrea, C.: Long-term slip rates and characteristic slip: keys to active fault behavior and earthquake hazard, Earth Planet. Sci. Lett., 333, 483-494, 2001.
Taylor, M. and Yin, A.: Active structures of the Himalayan-Tibetan orogen and their relationships to earthquake distribution, contemporary strain field, and Cenozoic volcanism, Geosphere, 5, 199-214, 2009.

Taylor, M., Yin, A., Ryerson, F., Kapp, P., and Ding, L.: Conjugate strike slip fault accommodates coeval north-south shortening and east-west extension along the Bangong-Nujiang suture zone in central Tibet, Tectonics, 22, 1044, doi:10.1029/2002TC001361, 2003.

Thiede, R. C. and Ehlers, T. A.: Large spatial and temporal variations in Himalayan denudation, Earth Planet. Sci. Lett., 371-372, 278-293, 2013.

Trifonov, V. G.: Using active faults for estimating seismic hazard, J. Earthquake Pred. Res., 8, 170-182, 2000.

Trifonov, V. G. and Kozhurin, A. I.: Study of active faults: theoretical and applied implications, Geotectonics, 44, 510-528, 2010.

United Stated Geological Survey (USGS): Largest and Deadliest Earthquakes by Year: 1990-2014, available at: http://earthquake. usgs.gov/earthquakes/eqarchives/year/byyear.php (last access: 24 July 2015), 2014.

Washburn, Z., Arrowsmith, J. R., Forman, S., Cowgill, E., Wang, X. F., Zhang, Y., and Zhengle, C.: Late Holocene earthquake history of the Central Altyn Tagh Fault, China, Geology, 29, 1051-1054, 2001.

Washburn, Z., Arrowsmith, J. R., Dupont-Nivet, G., Feng, W. X., Qiao, Z. Y., and Zhengle, C.: Paleoseismology of the Xorxol Segment of the Central Altyn Tagh Fault, Xinjiang, China, Ann. Geophys.-Italy, 46, 1015-1034, 2003.

Wesnousky, S. G., Kumar, S., Mohindra, R., and Thakur, V. C.: Uplift and convergence along the Himalayan Frontal Thrust of India, Tectonics, 18, 967-976, 1999.

Wills, C. J., Weldon II, R. J.,, and Bryant, W. A.: California fault parameters for the National Seismic Hazard Maps and Working Group on California Earthquake Probabilities, Appendix A in The Uniform California Earthquake Rupture Forecast, version 2 (UCERF 2): U.S. Geological Survey Open-File Report 2007-1437A, and California Geological Survey Special Report 203A, 48, available at: http://pubs.usgs.gov/of/2007/1437/a/ (last access: June 2015), 2008.

Zachariasen, J. and Prentice, C. S.: Detail mapping of the northern San Andreas Fault using LiDAR imagery, United States Geological Survey Final Technical Report 05HQGR0069, 1-47, available at http://earthquake.usgs.gov/research/external/reports/ 05HQGR0069.pdf (last access: July 2015), 2008.

Zubovich, A. V., Wang, X., Scherba, Y. G., Schelochkov, G. G., Reilinger, R., Reigber, C., Mosienko, O. I., Molnar, P., Michajljow, W., Makarov, V. I., Li, J., Kuzikov, S. I., Herring, T. A., Hamburger, M. W., Hager, B. H., Dang, Y., Bragin, V. D., and Beisenbaev, R. T.: GPS velocity field for the Tien Shan and surrounding regions, Tectonics, 29, TC6014, doi:10.1029/2010TC002772, 2010. 